\title{
ENKELE KRITIESE OPMERKINGS OOR DIE TEOLOGIESE GRONDSLAE VAN MENSEREGTE EN 'N TEOLOGIE VAN BEVRYDING
}

DR. C. J. MANS

\section{INLEIDENDE OPMERKINGS:}

Die vergadering van die Wêreldbond van Hervormde Kerke wat in Augustus 1970 te Nairobi gehou is, het besluit dat sy Teologiese Kommissie sekere sake moes bestudeer. Een van hierdie sake is die Theological Basis of Human Rights and a Theology of Liberation.

In 'n skrywe gedateer 1 Junie $1973^{1}$ ) versoek die Sekretaris van die Wêreldbond ook ons kerk om 'n verklaring oor hierdie onderwerp te maak met die oog op 'n teologiese beraad wat vir 1975 beplan word ten einde "some kind of Reformed consensus"') te bereik. Genoemde skrywe wys ook daarop dat hiercie opdrag aan sy Teologiese Kommissie die direkte gevolg is var: 'n werkstuk met 'n feitlik gelykluidende titel wat deur Jürgen Moltmann ${ }^{s}$ ) vir die Wêreldbond voorberei is.

\section{VERSOENING:}

Ten einde hierdie versoek, maar ook die hele aangeleentheid in die regte perspektief te sien, is dit nodig om verder op die volgende te let:

a) Die hooftema van die Wêreldbond se Nairobi-vergadering was "God Reconciles and Makes Free". Moltmann was die inleier van hierdie onderwerp"). Die vergadering het met besonder hoë waardering kennis geneem van Moltmann se voordrag. Dit is belangrik om hier noukeurig te let op hoe Moltmann in sy voorlopige studiestuk vir die Nairobi-vergadering versoening beskryf het: „(Reconciliation is) not just the restoration of the old creation and a repairing of the lamentable effects which have entered the world through man ... Reconciliation directed towards the new creation ... if reconciliation is not beginning

1) Sien Handelinge van die Kommissie van die Algemene Kerkvergadering (Julie-September 1973), No. 70, bl. 60 .

2) My kusivering.

3) Jürgen Moltmann, Theological Basis of Human Rights and of the Liberation of Mann, in Reformed World, vol. no. 8. Des. 1973, bls. 348-357. Tensy anders vermeld, is al die sitate uit hierdie werkstuk van Moltmann. Die kursivering is in feitlik alle gevalle my eie.

4) Moltmann se voordrag met die titel God Reconciles and Makes Free kan gevind word in Nairobi 1970 Proceedings of the Uniting of the General Council of the World Alliance of Reformed Churches (Presbyterian and Congregational)? Geneve 1970. bls. 63-76. Gesiteer: Nairobi 1970 . 
of change, it is merely the cheap and easy hallowing of existing injustices"s). Volgens Reformed and Presbyterian Press Service het Moltmann verder gesê dat ,hope for the end of times becomes a hope opposed to the status quo" sonder dat die status quo nader gepresiseer word. Daarom sê Moltmann moet die Christendom ,forward-looking”, „forward-moving” en ,revolutionizing the present" wees ${ }^{(5)}$.

Moltmann maak ook meer teologiese uitsprake oor versoening. So sê hy byvoorbeeld "Gods reconciliation is the living fountain of liberation for guilt-laden, dying men, for the humilated and offended, for the poor and the wretched"'). In hierdie sin praat Moltmann in een asem van twee soorte ",bevrydings" en dit is van groot belang dat 'n mens dit nie uit die oog sal verloor nie: God bevry hulle wat met sondeskuld belaai is, maar God bevry ook hulle wat verneder, beledig, arm en in taal van Franz Fanon, „die vervloektes van die aarde is". Dit is opmerklik dat dit vir Moltmann eintlik om versoening en bevryding in die sin van laasgenoemde groep gaan.

Moltmann maak egter ook behoudende uitsprake. Hy onderstreep dat dit God is wat versoen; "the crucified Christ alone is our reconciler and liberator"). Ons wil dan ook nie met hom oor hierdie behoudende uitsprake verskil nie. Maar by noukeurige ontleding van Moltmann se gedagtegang is dit duidelik dat hy eintlik nie so behoudend is nie. Dit word spoedig duidelik dat die versoening vir hom 'n gegewendheid, selfs 'n besit van dic versoende mens word en dan veral van die kerk. So sê hy dan byvoorbeeld dat God se versoening ,provides the ground on which, and the power by which to bring about reconciliations between mutually hostile men"9). Die kerk moet hierdie versoenings soek, maar die plek waar hy dit moet soek, kan net die plek wees waar Christus gely het ,and that means in the midst of the concrete situations of inhumanity in our society" ${ }^{10}$ ). Vir die kerk beteken dit dat ,we should consciously accept the suffering of our time, should take over the cry for freedom that comes from the heart of oppressed men and peoples and make it the object of our own yearning, and should answer it with the call to reconciliation. The world too, can be liberated through reconciliation" ${ }^{11}$ ), want die kerk is "really the reconciling body of Christ in the world"12).

7) Reformed and Presbyterian Press Service, no. 82, bl. 2. My kursivering. Gesiteer verder as RPPS.

6) Sien RPPS no. 82, bl. 2.

־) Nairobi 1970, bl. 63. My kursivering.

8) Nairobi 1970, bls. 67 en 69.

9) Nairobi 1970, bl. 69. My kursivering.

10) Nairobi 1970, bl. 70. My kursivering.

11) Nairobi 1970 , bl. 67. My kursivering.

12) Nairobi 1970, bl. 73. My kursivering. 
Die kerk of die versoende mense, uitgaande van hierdie „beginning” wat God gemaak het, gaan dan „,forward-looking”, "forward-moving" en "revolutionizing" vooit om die status quo te verander omdat die "hope for the end of times" teen die status quo is. En as hierby in gedagte gehou word dat die kerk die „cry for freedom" van die onderdruktes sy eie moet maak, kos dit nie veel verbeelding om te kan sien waarop hierdie gedagterigting van Moltmann moet uitloop nie. Uiteindelik moet dit lei tot rewolusie en geweld. Daarom moet van Moltann se Tcoogie van Bevryding niks anders verwag word as die Wêreldraad van Kerke se Teologie van Rewoiusie of van sy Teologie van Ontwikkeling nie. Moltmann is immers ook die groot denker by die Wêreldraad van Kerke se Teologie van Ontwikkeling ${ }^{13}$ ).

b) Verder is dit ook nodig om in gedagte te hou dat op hierdie vergadering die vereniging (versoening!) van die World Alliance of Reformed Churches en die International Congregational Council plaasgevind het.

Gesin in die lig van hierdie gebeurtenis, beteken versoening die versoaning tussen twee kerklike organisasies wat vroeër van mekaar verskil het. Versoening kan dan verstaan word in die sin van die opklaring van kerklike verskilpunte met die oog op groter kerklike eenheid of selfs 'n wyer ,,reformed consensus".

Moltmann se kritiek teen die kerke en die kerklike organisasies is dan ook besonder skerp. Die kerk is vir hom die ,reconciling body of Christ in the world", maar hierdie liggaam is eindeloos verswak, veral as gevolg van die feit dat die kerk meer versoen is met die ,privileges of their society and with the goodwill of the powers that be than with the crucified Christ" ${ }^{14}$ ). Die kerk is daarom nie meer 'n gelowige gemeenskap van Christus nie en moet deur die versoening tot hierdie diens bevry word.

Dit is opmerklik dat Moltmann se kritiek tcen die kerk sentreer rondom die sosiale vraagstukke. Dit gaan nie vir hom daarom dat die kerk gehoorsaam aan die Heer van clie kerk, kerk van die woord sal wees nie. Die kerk het by Moltmann nog net die taak om sosiale en politieke bevryder van die verdruktes te wees sonder dat hierdie "verdruktes" enigsins nader omskrywe word.

13) Moltmann is ook 'n gewaardeerde medewerker by die Wêreldraad van Kerke. So bv. het hy ook 'n voordrag gelewer voor die SODEPAX-beraad van Cartigny in Nov. 1969. Die titel van die voordrag is: The Christian Theology of Hope and its Bearing on Development. Dit is opgeneem in die SODEPAX-publikasie In Search of a Theology of Development, A SODEPAX Report, Lausanne 1969(?). Dit is opmerklik dat daar, wat tendens betref geen verskil tussen hiendie artikel en die onderhawige een in Reformed World is nie. „Theology of Development" en "Theology of Liberation" is sinonieme" en op hulle beurt is hulle weer eufemismes vir teologie van die rewolusie.

14) Sien Nairobi 1970 , bl. 64v. vir hierdie sitaat en Moltmann se kritiek op die kerk. 
c) Maar ook die feit dat die vergadering in Nairobi, die hoofstad van 'n swart Afrikastaat, plaasgevind het, is van betekenis. Hier kryversoening van 'n nog wyere en vir die ekumeniese beweging uiters belangrike betekenis naamlik dié van versoening tussen wit en swart, ras en ras ${ }^{15}$ ). Hierby ingesluit kan selfs ook die gedagte van versoening tussen die ontwikkelde en die ontwikkelende lande na vore kom.

In die boodskap ${ }^{16}$ ) aan sy lidkerke het die Wêreldbond vanuit die Nairobi-vergadering dan ook heelwat te sê gehad oor versoening. Die Boodskap volg die breë lyne oor versoening waarna ons hierbo onder a)-c) verwys het. Ons bepaal ons hier net by die teologiese uitsprake wat daarin oor versoening na vore kom.

Die boodskap begin met die aanhaling van 2 Kor. 5:19: , . . . dat God in Christus die wêreld met Homself versoen het deur hulle hul misdade nie toe te reken nie en die woord van die versoening aan ons toe te vertrou" God skep - aldus die Boodskap - die realiteit van die nuwe gemeenskap tussen Hom en sy skepping en tussen die mense. Die versoening tussen mens en mens het soos die tussen God en mens de facto geskied. Dit is nou 'n feitelike gegewendheid. Dit is die „beginning" van waaruit die versoendes nou die wêreld grondig moet verander, want hierdie versoende mense is ook die vrygemaakte mense wat juis bevry is "to share in the extention of his reality in every age and culture".

Dit word inderdaad selfs in die Boodskap gesê dat die versoening van God is, dat dit nie bestaan in ,human togetherness" wat gebaseer is op ,appeasement, sentimentality or clever manipulation of other people until they conform to our favourite programmes" nie. Dit word verder omskrywe as die vernuwing wat gebaseer is op God se woord van oordeel en vergewing. En dan ook uitdruklik nog verder: „It is the costly and joyous process of change, of personal and social conversion, in which God liberates us and enables us to move forward as hopeful people confident in his promise to make us fit instruments of his will". Alhoewel - aldus die Boodskap - God nie sy versoening tot sy kerk beperk nie, maak Hy tog die gelowiges vry om te kan onderskei tussen die valse messiasse en die opgestane Heer wat besig is om 'n nuwe mensheid tot volwassenheid te bring deur middel van

15) Dit spreek uit die volgende: ,.Meeting in Africa has, in refreshing and disturbing ways, deepened our realization of the turbulent glory of God's reconciling and liberating ways with men. The spontaneity and rejoicing, so vividly brought home to us as we worshipped together at the historic Church of the Torch at Kikuyu, and the exitement of being involved in God's work have made us to realize the extent to which many of us have grown morbidly accustomed to taking out sins more seriously than the transforming power of our risen Christ ..." RPPS no. 84, bl. 1.

16) Sien vir hierdie Boodskap behalwe RPPS no. 84 ook Nairohi 1970 , bls. 248-249. 
die menslike werk van sy Woord en sy Gees. Die vraag is natuurlik of hierdie sogenaamde volwasse mense dan instaat sal wees om selfstandig, dit wil sê sonder die Woord en die Gees soos Moltmann dit blykbaar wil hê, versoenena op te tree in die wêreld.

Maar as ons nou weer na 2 Kor. 5:19 mag kyk, dan lyk dit vir my dat in hierdie teks baie duidelik gestel is dat God in Jesus Christus altyd die enigste subjek van die versoening is. Verder is dit uit hierdie teks duidelik dat die versoening waarvan dit praat slegs geskied deur middel van skuldvergiffenis. En hier is dit ook tog baie duidelik wie die subjek van die skuldvergiffenis is, naamlik God wat ,hulle hul misdade nie toereken nie”. Verder is dit duidelik dat aan ons in hierdie teks die woord van die versoening toevertrou is, dit wil sê die verkondiging, die proklamering van hierdie werk van God in Jesus Christus. Dit is nie so dat ' $n$ mens homself of ander mense met God kan versoen nie. Dit sou blatante en onbeskaamlike kreatuur vergoding wees. Dit is God se werk in Jesus Christus deur die Heilige Gees. Niemand kan buite die geloof in Jesus Christus om met God versoen word nie.

Indien hierdie eksegese van 2 Kor. 5:19 korrek is, volg daaruit die volgende kritiese opmerkings:

Die versoeningsleer van die Boodskap is gebou rondom 'n Deïstiese Godsbegrip. God het eenmaal die versoening laat geskied. Dit het eenmaal vir alle mense, ongeag die geloof in die drie-enige God, plaasgevind. Dit is nou die beginpunt of vertrekpunt van die menslike versoeningsaktiwiteite. Die mens moet die baie skeidsmure tussen mens en mens, kerk en kerk, ras en ras, ensovoorts afbreek. Hy moet sodoende die wêreld waarin hy woon, radikaal verander. Van die hel van die status quo moet hy dan die paradys van grenslose ,versoende" mense maak waarin almal met mekaar versoen in onbeperkte vryheid sal lewe.

Dit is egter duidelik dat God nou nie meer die subjek van die versoening is nie. Die mens het die mag en werk oorgeneem. Hy is volkome in beheer. Maar dan is versoening inderdaad dit wat die Boodskap sê dit nie mag wees nie, naamlik ,human togetherness" wat gebaseer is op ,appeasement, sentimentality and clever manipulation". Dit is dan ook volkome duidelik dat 'n Christendom wat nie meer aanvaar dat net die woord van die versoening, en nie die versoening self, aan hom opgedra is nie, 'n „revolutionizing" mag in die wêreld moet word. Dit is hierdie soort aktiwisme wat, gekoppel aan 'n beheptheid met sekere politieke en sosiale aangeleenthede en 'n na links georiënteerde denke oor hierdie sake, uiteindelik, soos by die Wêreldraad van Kerke, moet uitloop op ,bombs for the world" in plaas van „Bread for the world". 
Dit is ook duidelik dat as 'n kerk nie meer genoeg het aan die woord van die versoening wat niks ander kan wees as die verkondiging van Christus nie, daardie kerk nie meer kerk van Jesus Christus kan heet nie. Dit is ook duidelik dat as die woorde ,hervormde konsensus" in hierdie verband gebruik word, die woord „hervormd" misplaas is! „Hervormd" kan in die kerklike en Bybelse taalgebruik sekerlik nie 'n beweging veg van Christus af wees nie, maar slegs een na Hom aandui.

Dit is cok duidelik dat as die versoening beskrywe word as 'n „process of change, of personal and social conversion" ons met presies dieselfde standpunt te doen het as dié wat Borovoy op die Wêreldraad van Kerke se Konferensie oor Kerk en Gameen. skap verkondig het.

Hierdie verwronge versoeningsleer lê ten grondslag aan dic Wêreldbond van Hervormde Kerke se studie oor die teologies: grondslae van menseregte en 'n teologie van die bevryding. Dit is die parallel van die Wêreldraad van Kerke sc studieprogram oo: die humanum en die teologie van die rewo'usie (of selfs van die teoiogie van ontwikkeling).

\section{TEOLOGIESE GRONDSLAE VAN MENSEREGTE EN TEO- LOGIE VAN BEVRYDING:}

Omdat Moltmann se reeds genoemde artikel in Reformed World bedoel is as "the first discussionstarter" is dit nodig dat ons breedvoerig hierop sal ingaan en dit van kommentaar sal voorsien.

a) Moltmann stel dat die ekumeniese beweging van sy begin af bewustelik verbonde was met politieke beweging; wat hulle beywer het vir die internasionale erkenning van menseregte. Ter stawing hiervan haal hy besluite aan van die Wêreldfederasie van Lutherse Kerke (Lund 1947 en Evian 1970) asook van die Uppsala-vergadering (Seksie IV) van die Wêreldraad van Kerke. Hy spreek voort sy mening uit dat dit tyd geword het om die teologiese basis van menseregte op te stel en dit dan ook so te doen dat die oproep tot menseregte nie tot blote verklarings beperk bly waaraan niemand hom eintlik steur of aan gebonde voel nie. Dit is vir hom 'n onomstootlike feit dat die sosiale en politieke koers wat die kerke ingeslaan het, universele betekenis verkry het juis as gevolg van hulle verhouding tot menseregte. Dit is immers eers ten opsigte van menseregte dat die kerk "church for others" of "church for the world" is. So het die Wêreldraad van Kerke se Programme to Combat Racism (Arnoldshain, September 1970) volgens hom as basis 'n teologie van menseregte. Die weerstand van sekere kerke teen hierdie antirassisme-program sou dan volgens hom gebore wees uit wat hy 
noem hulle traagheid om die kwessie van menseregte te bestudeer of hulle onvermoë om die christelike karakter van die verklarings van menseregte te erken.

Dit is duidelik dat dit vir Moltmann daarom gaan dat die menseregte wel in verskillende verklarings gestel en geaksentueer is, maar dat daar eintlik nog nie weë en middele bestaan om dit te implementeer nie. Dit wil lyk asof die teologie van menseregte en teologie van bevryding belangrik geword het vir die ekumeniese denke met die oog op die frustrerende impasse waarin die ekumeniese denke en optrede ten opsigte van menseregte verkeer. Dit is byvoorbaat ook reeds duidelik dat die kerk en volk van Suid-Afrika niks goeds van hierdie teologie van menseregte en teologie van bevryding sal kan verwag nie. Dit sal sonder enige twyfel lei tot 'n nuwe stortvloed van intimiderende beskuldigings en terselfdertyd dien as ' $n$ nuwe aansporing tot terroristiese bedrywighede in Afrika teen die blanke Suide.

Dit is ook ' $n$ baie interessante bewering en erkenning wat Moltmann maak as hy stel dat die sosiale en politieke koers van die kerke universele betekenis verkry het juis as gevolg van hulle verhouding tot menseregte. Met ander woorde hierdie beheptheid van die ekumeniese beweging met sosiale en politieke aangeleenthede het nie in die eerste plek 'n Bybelse fundering of selfs impuls nie. Dit moet nou bewys word langs die weg van 'n ver-christelike of dan wel ver-teologisering van die menseregte én van die bevrydingsaksie wat noodwendig uit die ver-teologisering van die menseregte moet volg.

Mo'tmann se siening van die apostolaat van die kerk gaan mank aan dieselfde soort van ding. Die kerk is eers kerk vir ander of kerk vir die wêreld ten opsigte van menseregte! Dit waarin hy kerk vir die wêreld moet wees, bestaan hier nie meer in die verkondiging van die deugde van Christus (1 Petr. 2:9) of in die kerstening van die wêreld nie (Mat. 28:19), maar in die beywering vir menseregte waarvan die christelik-teologiese aard daarvan nou eers ontdek en geformuleer moet word ${ }^{1}$ )!

Moltmann het hierdie problematiek blykbaar ook self aangevoel as hy in 'n latere artikel ${ }^{18}$ ) aandag gee aan wat hy noem „false alternatives" soos byvoorbeeld dié dat daar geen ,alternative . . . between evangelization and humanization" mag wees nie. Maar uiteindelik beteken evangelisasie vir Moltmann dan

1i) Moltmann sê self: „Theological tradition has perennially connected Christian practice and universal humanity by means of a Christian doctrine of natural law and a Christian doctrine of creation". Dit is ook belangrik om daarop te let dat by die Wêreldraad van Kerke se studie oor die humanun en die sosiale en politieke betrokkenheid van die kerke die herskrywing van die skeppingsleer beklemtoon is.

18) Jürgen Moltmann, Christian Theology and its Problems Today in Reformed World, vol. XXXII, no. 1 (Maart 1972). 
tog nie veel meer as ,involvement in the social and political problems of society" nie. Uiteindelik moet die christelike teologie tog ,a political theology" word. En uiteindelik is dit tog maar waar dat dit moeilik is "to wage a revolution without the Bible. (Block). It is even more difficult not to bring about a revolution with the Bible (Acts 17:6-7)".

Interessant is ook Moltmann se erkenning dat die Wêreldraad van Kerke se antirassisme-program gebaseer is op 'n teologie van menseregte (wat nog nie geformuleer is nie). Merkwaardig is egter sy stelling dat kerke se weerstand teen hierdie program volg uit hulle traagheid om menseregte te bestuder of die christelike karakter daarvan te erken! Het dit hom nog nooit opgeval dat dáár kerke teen hierdie antirassisme-program kan wees juis omrede van die onchristelike metodes en middele wat die Wêreldraad van Kerke hom daarin van bedien nie? Het dit hom ook nog nie opgeval dat hierdie antirassisme-program alleen weet van blanke rassisme en volkome blind is vir enige vorm van swart rassisme is?

b) Moltmann bied in sy genoemde artikel ook 'n geskiedenis van die Deklarasie van Menseregte.

Hy wys daarop dat die vroeëre kulture nie die abstrakte begrip „mens” geken het nie. Die denke was etnografies en het slegs die onderskeid ,lid van die stam" of „vreemdeling' geken. In hierdie geval het slegs lede van 'n betrokke stam vir daardie stam "regte" gehad.

Die begrip humanitas soos ons dit ken, het sy oorsprong in die filosofie van die Sofiste en Stoīsyne. Hier verval die onderskeid homo Romanus/,barbare” ten gunste van dié „,menslik”/ „onmenslik" wat sig dan uitstrek oor enige ander onderskeid wat tussen mens en mens gemaak kan word.

Dan volg Moltmann se weergawe van die Bybelse leer in hierdie verband. Adam was nie die eerste Jood nie, maar die eerste mens. Verder hou die feit dat die mens geskape is na die beeld van God in dat sy waardigheid (,dignity"), vryheid en verantwoordelikheid verhewe is bo elke organisasie van die menslike gemeenskap of selfs die staat. Verder: as God in die verontmenslikende geskiedenis optree as die Bevryder van die mens, dan moet die einddoel van Israel, maar ook van die Christendom die nuwe regverdige mensheid van God wees. Die historiese monoteīsme van die Ou Testament lei noodwendig tot die ideaal van die een mensheid. Die laat-Joodse verwagting van die komende koninkryk van die Seun van die mens (Dan. 7) wat die beesagtige koninkryk van die wêreld sal vernietig, maar ook die Christe. like proklamasie van Christus as die Seun van die Mens en die

19) My kursivering. 
nuwe mens, openbaar 'n teologiese en toekomsgerigte opvatting van die mensheid. Dit is egter nie die gemeenskaplike menslike natuur wat die mense saambind nie, maar die aan almal gemeenskaplike definisie in terme van die beeld van God en hulle gemeenskaplike toekoms in die koninkryk van God.

Die menseregte tree eers in die $16 \mathrm{de}$ eeu na vore as instrumente in die politieke stryd om geregtelike sekuriteit van die individu teenoor die mag van die staat te verseker. Hierdie ontwikkeling van die menseregte, is volgens Moltmann, nog nie afgeloop nie.

Die kerstening van die Europese state het die verhouding van die individuele mens tot die staat op twee wyses verander:

a) As die mens die beeld van God is, is hy 'n verantwoordelike persoon en draer van die regte en verpligtinge van vryheid. Die mens bestaan nie ter wille van die staat nie, maar die staat ter wille van die mens.

b) Daarom is die staat nie meer „God op aarde” nie, maar hy moet die waardigheid van die mens respekteer en handhaaf. Menseregte is dus ten opsigte van die owerheidsinstellings basiese regte. Owerheidsgesag en burgerregte moet beoordeel word vanuit hierdie basiese regte. Dat die owerheidsgesag nie vanselfsprekend is nie, maar geregverdig moet word, is volgens Moltmann die resultaat van die kerstening van die staat.

In die Middeleeue bly twee sake langs mekaar staan: enersyds die godsdienstige en teoretiese reg van die menslike vryheid maar andersyds ook die sosiale en politieke onvryheid. Eintlik was dit net die adelstand wat vir hulle sekere voorregte bekom en verseker het deur sekere kontrakte met die verskillende monargië aan te gaan. Hiermee het die idee van die staatskontrak ontstaan. Dit het tot 'n mate 'n bindende effek op die owerheidsgesag gehad. So byvoorbeeld ontwikkel die puriteine die „Rights of Parlement" in die "Petition of Rights” (1628) en die „Bill of Rights” (1889). Met die Amerikaanse „Declaration of the Rights of Virginia" (1776) is die staatskontrak gewettig deur sy opname in die konstitusie. Die konstitusie erken die menseregte as "the basis and foundation of government". Verder: „All men are by nature created equally of free and independent and possess cerain unalienable rights". Hier ontbreek vir Moltmann egter nog die spesifieke ,intention . . . with regard to the concrete distinctions between rights and property among the whites and slaves, rich and poor". Dit het wel gevolg in die Franse Konstitusie van 1791. Volgens Moltmann is die staat gedurende die 19de eeu gebruik om die menseregte en individuele vryhede van die mens te beklemtoon en te bewaar. 
Uit die Russiese Rewolusie volg dan die konstitusie van die verontregtes teenoor die uitbuiters. Art. III van die Konstitusie van die Russiese Gefedereerde Kongres van Republieke (1918) bevat die volgende stelling wat vir Moltmann van besondere betekenis is: ,in struggle to destroy every exploitation of man by man, every class division of society, unmercifully to crush the exploiters".

In Europa het die fasistiese skrikbewind gelei tot die Atlantic Charter (1941) en na die oorlog tot die totstandkoming van die Verenigde Volke (1945). Laasgenoemde se Universal Declaration of Human Rights word tot nou toe erken as die internasionale bindende verklaring oor menseregte. Moltmann onderstreep dat in hierdie Verklaring die toekomstige karakter van die menseregte gehandhaaf is. Die Verklaring stel dat dit "the common ideal to be attained by all peoples and nations" is. Daarom bevat dit - aldus Moltmann - nie net 'n ,declaration of the basis" nie, maar ook 'n verklaring oor die ,intention". Daar is egter geen voorsiening gemaak vir die praktiese deurvoering van die ideaal nie omdat die Verenigde Vo:ke ,lacks the power of realization".

Moltmann se kursoriese oorsig oor die geskiedenis van die menseregte bring vanweë die eensydigheid en vooringenomenheid daarvan ernstige vrae na vore. Ons noem enkele voorbeelde. In dien die mens slegs onvervreembar: rezte en nie net slegs voorregte het nie en indien die staat se roeping slegs daarin sou bestaan om die regte van die individu soos byvoorbseld sy vryheid te waarborg en te handhaaf, móét die staat uiteindelik waarborg word van chaos en anargie. In so 'n staatshuishouding sal daar geen sprake kan wees van reg en orde nie. Daar bestaan ook seker geen twyfel daaroor dat die Kommunisme Moltmann se standpunt van harte sal verwelkom nie. Dit sal die Weste - wat immers vir die Kommunisme volgens die gesiteerde Konstitusie die uitbuiters is wat vernietig moet word - totaal verlam en blootstel aan kommunistiese oorname.

Wat die teologiese aspek betref, is daar ewe-eens verskuiwings van ernstige aard by Moltmann. Die menseregte word sommer maar afgelei uit die feit dat die mens geskape is na die beeld van God sonder om die feit van die sondeval in aanmerking te neem. Hy maak ook geen verskil tussen hulle wat glo, dit wil sê in Christus is en hulle wat nie glo nie, dit wil sê buite Christus is nie. Daar kan immers net van 'n nuwe mens in Christus gepraat word. Die ,in Christus" is die enigste bestaansfeer van die nuwe mens. Of bedoel Moltmann dalk die „nuwe mensheid”? Indien wel, verkeer hy in die onmiddellike nabyheid van die alversoening. 
'n Verdere indruk wat 'n mens kry by Moltmann se oorsig, is dat sy belangstelling in die menseregte en 'n teologie van die bevryding daarin sy dryfkrag het dat hy 'n pad wil vind vir die Verenigde Volle uit sy dilemma, naamlik dat hy nie instaat is om die ideaal van menseregte te implementeer nie.

c) Moltmann wy voorts sy aandag aan die teologiese probleme ran menseregte. Hy wys weer eens daarop dat die menserorte gegroei het uit die kerstening van die maatskappy en die staat. Die kcrsteningsproses vind plaas tussen die spesifieke kenklike lewe $n$ die folitieke lewe in die algemeen. Dit kan op twee maniere ģıskied naamlik ewolusionêr of rewolusionêr. Die manier waarop dit geskied, is egter vir Moltmann nie belangrik nie. Belangrik vir hom is alleen of die huidige stryd om ' $n$ beter menslikheid en meer radikale bevryding so geskied dat dit in 'n bepaalde verhouding tot die kersteningsprosesse staan. Indien nie, sal hierdie hele saak van 'n beter menslikheid en radikale verandering in die lug hang. Die rewolusie van die vryheid ken immers ook die tradisie van die vryheid en hy moet dit in hom opnecm.

Ons kan die hele redenasie van Moltmann soos volg saamvat: Die stryd om ' $n$ beter menslikheid en radikale verandering moet gebind wees aan die kersteningsprosesse wat ewolusioncr of rewolusionêr kan wees. Rewolusionêre optrede ter bereiking van die gestelde doelwitte is dus vir Mo!tmana volkome toelaatbar want dit is volgens hom wel 'n toelaatbare kerstoningsproses. Watter Bybelse gronde hy hiervoor kan aanvoer sou 'n mens nogal kennis van wou neem.

Die begrip ,radikale verandering" laat ook 'n onaangename smaak. Dit is deel van die begripsmateriaal van die neo-marxism? wat terselfdertyd ook 'n stywe klap weg het van die anargisme. Hierdie neo-marxistiese denke oor „change" as "radical change” het lankal reeds burgerreg in die ekumeniese denke verkry. Die volgende sitaat uit 'n artikel van Roger Garaudy is hier ter sake:

". . . what characterizes this Christian revolutionary tradition from Joachim of Fiore to John Huss, from Thomas Münzer to the theologies of hope and political theologies of our own day, is that the Kingdom of God is not conceived as another world in space and time, but as a different world, a changed world, a world changed by our own efforts. The Kingdom of God is not a promise we have passively to wait to be fulfilled but basically a task to be accomplished"'2u).

Vir Garaudy is dit 'n uitgemaakte saak waar nie net Moltmann se Teologie der Hoffnung maar ook sy theology of liberation staan nie. Dit is die teologie wat die koninkryk van God deur

20) Roger Garaudy, Faith and Revolution in Ecumenical Review, vol. XXV, no. 1, Jan. 1973, bls. 66 en 67. 
menslike inspanning op hierdie aarde en in hierdie tyd wil oprig - Teologie wat niks, nie eers die Bybel ontsien om sy ideale te verwesenlik nie.

Moltmann is egter nog lank nie uitgepraat nie. Hy stel dit duidelik dat die verklarings oor menseregte net in soverre effektief is as wat daar mense is wat bereid is om hierdie regte en verpligtings op te neem en in belang van die mensheid op te staan vir die onderdruktes. Die regte van die vryheid is slegs in soverre effektief as wat daar mense is wat intree vir die bevryding van verdrukte mense. Dit is vir Moltmann 'n uitgemaakte saak dat dit eintlik die werk van die kerk is. Die Christendom moet 'n werklikheid vir menslikheid en vryheid aktualiseer wat instaat sal wees om menseregte met sosiale en politieke lewe te vul.

Moltmann stel twee prinsipiële vrae ten opsigte van die Universal Declaration of Human Rights:-

Die eerste vraag is: Watter funksie kan dit dien?

Dit kan dien as die universele basis van die verskillende nasionale konstitusies. Die burgerregte is dan gebaseer op menseregte. Wat moet egter in die geval van konflik voorrang geniet: burgerregte soos verskans in die basiese menseregte of die veiligheid van die staat?

Die swakheid van die menseregte is daarin geleë dat daar te min magte bestaan om dit teenoor ongeregtigheid en verdrukking te realiseer. Dit kan selfs misbruik word om verdrukking voort te sit. Met ander woorde, sê Moltmann, wat eintlik nodig is, is om die verhouding te bepaal tussen die teorie van menseregte en die praktiese toepassing daarvan ten einde alle moontlike misverstande uit te skakel. Die praktiese vervulling van die menseregte is menslikheid vir die onderdruktes. Die praktiese verwerkliking van die vryheid is om die verdruktes te bevry. Dan volg Moltmann se slotsom: „The practical function of this general declaration of human rights therefore can only be revolutionary".

Die verdere vraag wat Moltmann stel, is: in watter opsig moet die Verklaring van Menseregte dan uitgebrei word as dit nie net 'n idealistiese, maar 'n rewolutionêre betekenis moet hê? Hy meen dat die menseregte veral ten opsigte van sosiale verpligtings uitgebrei kan word. Dit is vir hom van beslissende belang dat die regte wat die vryheid van die individu waarborg, omgesit sal word in verpligtings om hulle te bevry van wie hierdie regte weerhou word. As die menseregte nie in die lug moet hang nie, is dit noodsaaklik dat hulle geformuleer moet word met die oog op hulle uitvoerbaarheid. Hy meen dat tot nou toe ook nie in die Verklarings oor menseregte voorsiening gemaak is vir noodsaaklike lyding wat in die stryd om bevryding vervat is nie. 
Moltmann se doelstelling is, wat die uitbreiding van die menseregte betref, dus hoofsaaklik gerig op die uitvoerbaarheid, die toepassing daarvan. Sonder die reg en mag om dit af te dwing, veral die rewolusionêre karakter daarvan, is dit niksseggend.

'n Verdere vraag waarop Moltmann ingaan, is: Watter teologiese verbande wat in die lig van die voorafgaande bruikbaar sal wees, bestaan daar tussen die Christelike geloof en die tradisie van menseregte?

Vroeër - sê hy - is hierdie verband gelê met 'n beroep op die natuurlike wet. Hy self het die volgende oplossing: Daar moet begin word by die bevryding van die onvrye mens deur geloof, liefde en hoop om sodoende die teorie te skets wat hierdie gebeurtenis van bevryding fundeer en dit universeel bindend sal maak en wat dit doen deur die mens te definieer in terme van die vryheid van sy geskape-wees na die beeld van God. Die vertrekpunt moet dus die bevryding in praktyk wees om dan later die teorie uit te werk wat hierdie historiese gebeurtenis verbind met die hoop op die menslike koninkryk van die nuwe mens en wat toeganklik is vir alle mense. Moltmann beweer dat ons vir hierdie soort denke duidelik voorbeelde in die Bybel het. Die eerste voorbeeld wat hy noem, is dié van die bevrydingsgeskiedenis van Israel in Eksodus. Israel se teologiese refleksie het begin by God as Bevryder soos Hy ervaar is in die eksodusgeskiedenis. Eers later is hierdie teologiese denke uitgebrei. Die God van die bevryding is ook die Skepperheer. Só ook in die Nuwe Testament. Dit begin met die belydenis dat Jesus Christus die Bevryder (in konkrete sin) is en gaan eers daarna oor tot die skepping en eskatologie.

Vertaal in terme van 'n teologie van menseregte beteken dit dat ons moet begin met die konkrete teologie van bevryding. In hierdie teologie moet die algemene vryheid as algemene menslike reg saam met die gemeenskaplike toekoms van hierdie vryheid as die nuwe mensheid (of menslikheid) gestel word. Moltmann glo dat met hierdie konkrete beginpunt vermy kan word dat die teorieë van die verklarings oor die vryheid van die mens misbruik kan word. Voorts meen hy dat hierdie studie teologies langs die volgende drie stappe moet geskied:

"1. Christian Theology is a theology of liberation, for it understood Christ in the comprehensive sence as liberator.

2. The theology of liberation is the Theology of man, for every man is defined by his similitude to God.

3. The theology of liberation is the Theology of the future, for the Kingdom of the Son of Man is the human future of man". 
Moltmann stel 'n aantal vrae rondom elkeen van hierdie drie punte. Die vrae is insiggewend met die oog op die koers wat Moltmann se denke inslaan:

a) Christoike teologie is bevrycingsteologie omdat Christus in omvatten:a sin die Bevryder is.

1. Hoe lyk die Bybel as dit gelees word deur die oë van die armes, onderdruktes, ensovoorts?

Op 'n ander plek praat hy selfs van die Bybel as 'n boek van die armes. Die armes is die „menschliche Ort wo Christus präsent" is $^{21}$ ). Daar bestaan vir Moltmann selfs 'n messianisme van die a.mes. Die armes is ' $n$ apokaliptiese geleentheid. Hier is oordeel en bevryding en nie net geleentheid vir barmhartigheidsdiens nie. Hulle het teologiese betekenis. Hulle bied 'n hermeneuse van die werksaamheid van God. Hulle is nie net teken van elkeen se toestand nie (soos die Gekruisigde dit eerste is), maar hulle is die plek waar God self teenwoordig is ${ }^{22}$ ).

2. Christus is deur sy tydgenote konkreet as Bevryder beleef. Van wat wil die Christendom die mense bevry in die dissipelskap van die Here? Is geloof 'n konkrete gebeurtenis van bevryding of is dit geloof in ' $n$ vryheid wat nie bestaan nie? Christus is die Bevryder uit elke onvryheid en onmenslikheid. Hy is nie net godsdienstige Bevryder nie.

3. Christus is deur die onderdruktes as Bevryder ervaar. Hy is egter gekruisig deur die owerste van hierdie wêreld volgens die wet. As hierdie owerste van die wêreld die Christendom nie vandag vervolg nie sal hy tog graag die Christendom wil beroof van sy gevaarlike bevrydingsmag. Wie is Christus? Heer van die hemel, 'n nuwe wetgewer of die bewaarder van die status quo?

b) Die bevrydingsteologie is die teologie van die mens omdat dit die mens beskou vanuit die beeld van God. As dit waar is, sê Moltmann, dan kan die Christelike praktyk nie meer net in kerklike kringe geskied nie. Die vraag na die mens moet in die vraag na die kerk opgeneem word.

Nou is die vraag: vir wie is die vraag na die mens die belangrikste? Moltmann antwoord: vir die mens wat verontmenslik is. Daarom kan die kerk nie vir alle mense bestaan nie, maar alleen vir hulle wat beroof is van menseregte en vryheid. En verder: die kerk kan nie die gemeenskap van armes en verdruktes wees as hy nie eers sy bande met die onderdruktes van hierdie mense breek nie.

21) Moltmann in Kirche im Prosesz der Aufklärung, bl. 48 .

22) Hierdie opvatting van Moltmann is miskien die duidelikste uitgewerk in sy Theologie der Hoffnung, bl. 208. God se Koninkryk is sub contrario aanwesig. 
Watter middele kan die kerk nou gebruik vir die bevryding van die mens tot vryheid? Sal dit missionêre of ook humanitêre middele wees? En wanneer is die gebruik van rewolusionêre mag noodsaaklik vir die bevryding van die onderdruktes? Bestaan daar in die lig van die Verklaring oor menseregte geïnstitueerde tirannie, polities deur middel van militêre klieke, rassisties deur middel van die dominering deur 'n blanke groep, sosiaal deur die van 'n eksploiterende klas? As 'n tirannie nie reg tot mag het nie, is rewolusie dan geoorloof? Het die mens reg tot rewolusie, ensovoorts?

So stel Moltmann ook sy vrae rondom die teologie van bevryding as teologie van die toekoms. Hy het egter sy punt reeds duidelik genoeg gemaak sodat ons sy vrae hier maar links kan laat lê. Die koers wat die denke van die Wêreldbond van Hervormde Kerke oor 'n teologie van bevryding sal inslaan, is met hierdie artikel van Moltmann eintlik klaar aangedui.

\section{A. ONS KAN MOLTMANN SE GEDAGTEGANG SOOS VOLG SAAMVAT:}

\section{A. Menseregte:}

1. Die huidige algemeen aanvaarde Verklaring oor Menseregte is dcur die Verenigde Volke opgestel.

2. Die Verenigde Volke het egter nie die mag en die middele om die menseregte te implementeer nie. Dit is daarom "teorie" wat selfs vir verdere onderdrukking misbruik kan word.

3. Moltmann, en met hom saam die Wêreldbond van Hervormdc Kerke, wil blykbaar met die teologie van menseregte en die teologie van bevryding een van twee dinge, of dalk albei, doen:

a) die Verenigde Volke aanspoor om meer militant te wees;

b) die Wêreldbond van Hervormde Kerke vir hierdie doel mobiliseer deur sekere voorbehoude soos byvoorbeeld die gebruik van rewolusionêre mag, te rysmier.

4. Die menseregte kan uitgebrei word veral ten opsigte van sosiale verpligtinge en lyding ter wille van bevryding.

\section{B. TEOLOGIESE FUNDERING VAN MENSEREGTE:}

Twee sake is belangrik vir Moltmann se teologiese fundering van menseregte:

a) Die menseregte word afgelei uit die feit dat die mens geskape is na die beeld van God.

b) Dat die mense hulle gemeenskaplike toekoms in die Koniakryk van God het. 


\section{TEOLOGIE VAN BEVRYDING:}

\section{Wat is die teologie van bevryding?}

Dit is die teologie waarin die algemeen menslike vryheid as algemeen menslike reg gestel word en die gemeenskaplike toekoms van hierdie vryheid as die nuwe mensheid aanvaar en geleef word, of anders gestel: dit is die teologie wat die algemene menseregte moet verwesenlik.

2. Hierdie teologie van bevryding word Christologies gefundeer. Christus is in die wydste betekenis van die woord Bevryder net soos God in die Ou Testament die God van die Eksodus is. Christus is konkreet die Bevryder van die armes, onderdruktes, ensovoorts. Die Bybel is die boek van die armes wat op hulle beurt 'n apokaliptiese geleentheid bied omdat God juis in hulle werk op aarde.

3. Daarom moet die kerk net soos Christus, aan die kant van die armes en onderdruktes staan net soos $\mathrm{Hy}$ konkreet vir hulle die stryd voer.

Die kerk kan nie kerk vir almal wees nie maar slegs vir hierdie mense. God werk immers daar waar die armes, onvryes en diesulkes is. Die heil is vir die armes en kom deur die armes. Die kerk het in hulle 'n apokaliptiese geleentheid. In hierdie werk is die gebruik van rewolusionêre mag nie uitgesluit nie.

\section{VERSOENING:}

Die teologie van bevryding is gebaseer op 'n bepaalde versoeningsleer.

Die versoening het de facto in Christus plaasgevind en is die werk van God. Dit is egter as sodanig dıe beginpunt vanwaaruit die versoendes in die kerk versoening in die wêreld te weeg moet bring, tussen kerk en kerk, volk en volk, ras en ras.

\section{E. KRITIESE OPMERKINGS:}

Samevattend kan ons die volgende kritiese opmerkings maak:

1. Moltmann gaan uit van 'n eensydige en daarom valse Christologie. Hy noem Christus inderdaad Bevryder in die wydste sin van die woord. Dit word egter heeltemal op die agtergrond geskuiwe dat Christus die Bevryder van die sonde wat skeiding maak tussen ons en God is. Vir hom is Christus in die laaste instansie Bevryders van die armes en die onderdruktes in konkrete sin. Die armes verkry dan by Moltmann 'n heel eienaardige betekenis. Christus word op hierdie wyse verpolitiseer, ja selfs verrewolusioneer! Hy verlos, maar dan nie van wat jy self teen God en jou naaste gesondig het nie maar van dit wat die ekspoiteerders en die onderdrukkers aan jou gedoen het en nog doen. Laasgenoemde se optrede in die werreld is die eintlike sonde. 
2. Uit 'n verkeerde Christologie volg egter noodwendig verder 'n hele rits verkeerde opvattings. Trouens, dit is nie moontlik om met 'n verkeerde Christologie oor enige ander leerstuk van die Christelike teologie reg te dink nie.

Die eerste verkeerde opvatting wat daaruit volg, is 'n verkeerde antropologie. Sondermeer word uit die mens se geskapewees na die beeld van God die teologiese, selfs Christelike karakter van die menseregte geponeer. Dat daar so iets soos 'n sondeval plaasgevind het wat 'n absoluut verwoestende effek op die mens as beelddraer van God gehad het en nog het, word eenvoudig verbygegaan.

Daarom word die werk van Christus in die wêreld hoe langer hoe meer verhorisontaleer, versosialiseer en verpolitiseer. Sy versoeningswerk word - om by 'n tweede saak te kom wat uit hierdie verkeerde Christologie voortvloei - iets wat de facto geskied het en nou 'n gegewendheid is, 'n beginpunt van waaruit die kerk nou die versoening in die wêreld moet voortsit tussen allerlei groepe, persone en rasse.

Verder word die kerk 'n sosiale en politieke instrument in die hand van groepe mense wat hulle om verskillende redes vir die sogenaamde verdruktes van die aarde inset. Die kerk word soos sy Heer verpolitiseer en versosialiseer. Die kerk word in die taal van die neo-marxisme 'n „change agent", 'n rewolusinêre mag in die wêreld. Dit is nie uitgesluit dat hy ook meer advokaat vir geweld sal word en self ook geweld sal gebruik nie. Dus tussen hierdie teologie van die bevryding en die Wêreldraad van Kerke se teologie van die rewolusie of selfs teologie van ontwikkeling is daar alleen maar 'n naamverskil. Miskien gaan die Wêreldbond van Hervormde Kerke dalk nog 'n bietjic verder as die Wêreldraad van Kerke as Moltmann eintlik die doelstelling het om die Verenigde Volke self van die reg tot optrede te voorsien.

Maar dit is verder ook duidelik dat die ganse apostolaat van die kerk, as die middel waardeur God die wêreld wil bevry van die sonde deur dit langs hierdie weg vir Hom te wen, by Moltmann en die Wêreldbond van Hervormde Kerke verlore gegaan het. Eintlik is die apostolaat van die kerk die enigste teologie van bevryding wat die kerk kan ken en die verkondiging van die evangelie die enigste bevrydingsaksie wat aan die kerk opgedra is deur die Here en dan ook net onder die wete en die verwagting dat God, deur die werking van die Heilige Gees, deur middel van die verkondiging van sy kerk, self Bevryder van die mens uit die slawehuis van die sonde sal wees waar en wanneer dit Hom behaag. Hy bly in alles soewerein God. 